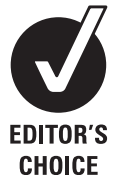

Global Public Health Unit, Social Policy, School of Social and Political Science, University of Edinburgh, Edinburgh, UK

\section{Correspondence to} Nathaniel Wander, Senior Research Fellow, Global Public Health Unit, Social Policy, School of Social and Political Science, University of Edinburgh, Chrystal Macmillan Building, 15a George Square, Edinburgh EH8 9LD, UK; nathaniel.wander@ed.ac.uk

Received 7 June 2010 Accepted 3 October 2010

\title{
Uneasy money: the Instituto Carlos Slim de la Salud, tobacco philanthropy and conflict of interest in global health
}

\author{
Tiffany Burch, Nathaniel Wander, Jeff Collin
}

\section{ABSTRACT}

In May 2007, the Instituto Carso de la Salud-now Instituto Carlos Slim de la Salud (ICSS) - was endowed with US\$500 million to focus on priority health issues in Latin America, notably issues of 'globalisation and noncommunicable diseases'. ICSS was soon criticised, however, on the grounds that its funding was derived from tobacco industry profits and that its founder Carlos Slim Hélu remained an active industry principal. Collaboration with ICSS was said to run counter to the WHO Framework Convention on Tobacco Control. The Institute's then Executive President Julio Frenk disputed these charges. This research employs an archive of tobacco industry documents triangulated with materials from commercial, media, regulatory and NGO sources to examine the financial relations between Slim and the tobacco industry. The paper analyses Slim's continuing service to the industry and role in ICSS. It demonstrates a prima facie conflict of interest between ICSS's health mission and its founder's involvement in cigarette manufacturing and marketing, reflected on ICSS's website as a resounding silence on issues of tobacco and health. It is concluded that the reliance of international health agencies upon the commercial sector requires more robust institutional policies to effectively regulate conflicts of interest.

The Instituto Carlos Slim de la Salud (ICSS) or Carlos Slim Health Institute (originally Instituto Carso de la Salud), was founded as a health charity by Mexican businessman Carlos Slim Helú and inaugurated on 18 September 2007 by Mexican President Felipe Calderón and Sra. Vivian Fernández, wife of the president of Panama. ${ }^{1}$ Backed by health and political elites, ICSS looks set to play an important role in Latin American public health. It helped sponsor the 2008 XVII International AIDS Conference in Mexico City ${ }^{2}$; it is partnering with the Clinton Global Initiative and the Mexican National Institute of Public Health in a US\$2 million breast cancer awareness initiative for Latin America and the Caribbean ${ }^{3}$; and alongside the Gates Foundation and the Spanish Agency for International Development Cooperation it is intended to be a key supporter of a Mesoamerican Institute of Public Health, part of Mexico's national and regional strategy to improve maternal and child health. ${ }^{4}$ In June 2010, the Inter-American Development Bank together with ICSS, Gates and Spain announced Iniciativa Salud Mesoamérica 2015, a 5-year collaboration 'to reduce health inequities ... in Central America and Southern Mexico ... [and] to support ... governments of this region to achieve the health Millennium Development Goals'. 6
The August 2007 WHO Bulletin applauded the upcoming launch of ICSS, endowed by its founder with US\$500 million to address priority health issues, notably 'globalization and non-communicable diseases'. (See the Institute's website for the breadth of missions included under this rubric. ${ }^{8}$ ) Former Mexican Health Minister and then Institute Executive President Dr Julio Frenk, ${ }^{9}$ twice candidate for Director-General of the $\mathrm{WHO}^{10}{ }^{11}$ and now Dean of the Harvard School of Public Health, ${ }^{12}$ described ICSS's 'new model' as one 'that has its own internal people carry out prospective analyses, define an agenda on the basis of that analysis and actively pick partners to ... carry out that agenda'. A total of 10 prominent health and development experts announced themselves in the Lancet as 'the Carso International Advisory Committee', ${ }^{13}$ explaining ICSS's priorities as encompassing work on infection, malnutrition, reproductive health, emerging diseases and 'challenges due to the globalisation of health risks'. ${ }^{13}$

However, ICSS's emergence and prominence raises fundamental questions for international health. Slim, one of the world's richest men, ${ }^{14-17}$ whose holdings include telecommunications, finance and retailing, ${ }^{18}$ also owns a $20 \%$ stake in the Mexican cigarette manufacturer Cigarrera La Tabacalera Mexicana (Cigatam), with the majority interest currently held by Philip Morris International (PMI). ${ }^{19}$ Having previously served on the board of Philip Morris Companies, Inc. (renamed Altria in 2003), Slim joined the board of PMI when it was spun off from the Altria parent in April 2008. ${ }^{19}$ His annual compensation from PMI includes a retainer of at least US $\$ 100000$, reimbursement of travel and business expenses and shares worth US\$140000. ${ }^{19}$

While the tensions in Slim's simultaneous roles as health philanthropist and tobacco industry executive went unremarked in initial Bulletin ${ }^{7}$ and Lancet $^{13}$ articles, the then editor of Tobacco Control Simon Chapman described Slim as 'a direct beneficiary of massive sales of tobacco', and questioned how ICSS advisory committee members reconciled this with 'the spirit and obligations of WHO's Framework Convention on Tobacco Control'. ${ }^{20}$ (See also Chapman ${ }^{21}$ ) Article 5.3 of the Framework Convention on Tobacco Control (FCTC) outlines a commitment 'to protect [tobacco control] policies from commercial and other vested interests of the tobacco industry'. ${ }^{22}$ Subsequent guidelines for its implementation clarify that this encompasses 'protecting against interference not only by the tobacco industry but also ... by organisations and 
individuals that work to further the interests of the tobacco industry' (emphasis added). ${ }^{23}$

In responding to this critique, Executive President Frenk minimised Slim's tobacco holdings and insisted that ICSS's endowment was based entirely on shares from the telecommunications company América Móvil and the infrastructure development corporation Ideal: 'No funds whatsoever derive from any financial or industrial interests in the tobacco industry' (emphasis added). ${ }^{18}$ Chapman's response to Frenk was rejected, ${ }^{24}$ and subsequently, the issues have not been explored within the scientific literature, while ICSS's expanding governmental and NGO collaborations have heightened the need for such analysis.

This paper documents Slim's past and, more importantly, current involvement in tobacco corporations, detailing tobacco's significance in the development of his Grupo Carso (GC) and his historic and ongoing strategic value to the global tobacco industry. It examines apparent conflicts of interest issues raised by these relationships and concludes that such conflicts present wide ranging concerns for international health policy that extend beyond Slim's role in ICSS or tobacco industry involvement in health charities most generally.

\section{METHODS}

Litigation against tobacco companies in the USA has resulted in the public release of more than 11 million internal tobacco industry documents since $1998,{ }^{25-27}$ with new lawsuit discoveries required to be made available through $2008 .{ }^{28}$ In 2006, a US federal court extended this period for another decade, and additional documents continue to be added pending the final resolution of that suit. ${ }^{29}$ We searched this material via http:// legacy.library.ucsf.edu/ between April 2008 and November 2009.

From initial keywords including 'Carlos Slim', 'Cigatam' and 'Mexico', searches were expanded via snowball sampling, producing new search terms including dates, names and file storage locations. ${ }^{30}$ Approximately 300 relevant documents were retrieved, of which 42 were critical to this study. We also searched websites and media reports related to Slim, his businesses and philanthropy, to Altria and PMI, and to Mexico/Latin America and public health, and critically re-evaluated findings in light of expanding understandings as documents were triangulated across multiple media, regulatory, academic and public health sources. ${ }^{31}$

The analysis is subject to the usual limitations of archival research: the documents are not a systematic sample nor do they permit reconstructing the universe from which they arose. ${ }^{32}$ Many industry documents were withheld with court assent as being legally privileged and the magnitude of potentially relevant documents that were withheld, despite discovery requirements, is unknown. ${ }^{33}$

Further, while the 'ageing' of these documents may raise some methodological questions, they have been used here in corroboration with other sources in what has been termed tobacco documents-anchored research' (Edith Balbach, personal communication, 14 June 2010). The documents presented here substantiate a longstanding pattern of financial and political relations between Carlos Slim/GC and Philip Morris/Altria/PMI. We have further documented such relations up to the present through a wide range of institutional web sites, news reports, 'grey literature', financial filings, etc.

A clear further limitation to this analysis, however, arises from the difficulties in disentangling the relationships of profit, power and prestige involving Slim personally, GC and subsidiary and parallel businesses, Fundacion Carlos Slim and subsidiary charities including ICSS, the Slim family as a collective entity and individual Slim family members and/or dependents. This complexity is exemplified in the instance of the 1.5 million Altria shares reported as being owned by Slim, 'mostly indirectly through Inmobiliaria Carso', in 2005. ${ }^{34}$ In a 2009 US Security and Exchange Commission filing, Bronco Drilling-owned by Inmobiliaria Carso and the GC financial company Banco Inbursa ${ }^{35}$-was required to report that, due to their majority control of Inmobiliaria and Inbursa, Slim, his three sons and three daughters effectively constituted a legal entity that 'beneficially own[ed]' all of Bronco's shares. ${ }^{36}$ Similarly, as of
Figure 1 Carlos Slim/Grupo Carso tobacco timeline.

\section{Carlos Slim / Grupo Carso Tobacco Timeline}

\begin{tabular}{|c|c|}
\hline 1980 & Slim holding company, Grupo Carso (GC) incorporated (initially as Grupo Galas) \\
\hline 1981 & GC acquires majority control of Cigatam-Philip Morris (PM) owns $29 \%$ \\
\hline 1983 & Slim acquires majority control of Cigarerra la Moderna (CLM) \\
\hline 1984 & Slim forms financial holding company Grupo Financiero Inbursa (Inbursa) \\
\hline 1985 & Cigatam + CLM hold 75\% share of Mexican cigarette market / CLM sold to ally Garza Romero to avoid monopoly charges \\
\hline 1990 & Tobacco income funds GC's Telmex purchase / Cigatam's Tadesa + CLM's Agroindustrias LM replace Tabamex as chief leaf-buyers \\
\hline 1995 & Cigatam becomes \#1 Mexican domestic cigarette company \\
\hline 1997 & Cigatam + CLM control $98 \%$ of Mexican cigarette market / PM acquires $50 \%$ of Cigatam/Slim joins PM Board/ BAT acquires CLM \\
\hline 1999 & Slim hosts PM executives, Mexican President Zedillo \& ministers / PM contributes $\$ 100,000$ to Telmex Foundation to honor late Sra. Slim \\
\hline 2000 & Mobile phone company America Movil spun off Telmex / Slim invests heavily in depressed PM shares \\
\hline 2001 & Slim makes large profit selling PM shares on rising market \\
\hline 2003 & Philip Morris Companies, Inc. rebrands as Altria \\
\hline 2005 & Development corporation Ideal created out of Inbursa \\
\hline 2006 & Slim leaves Altria Board \\
\hline 2007 & $\begin{array}{l}\text { WHO Bulletin announces Instituto Carso de la Salud (now Instituto Carso de la Salud--ICSS) / President Calderón inaugurates ICSS / } \\
\text { PM acquires additional } 30 \% \text { of Cigatam }\end{array}$ \\
\hline 2008 & $\begin{array}{l}\text { Tobacco Control editor challenges ICCS \& Slim on tobacco links / Cigatam attains } 55 \% \text { of Mexican market / Altria spins off Philip Morris } \\
\text { International (PMI) / Slim joins PMI Board of Directors }\end{array}$ \\
\hline
\end{tabular}


2009, GC reports that 12 Slim relatives, including 3 sons and 2 sons-in-law, sit on the GC Board and occupy top executive positions in GC subsidiaries. ${ }^{37}$ While such relationships may be unexceptional among Mexican elites, they increase the latitude for patronismo, that is, control through relationships of family, dependency and social obligation. Consequently, what Slim effectively controls may be substantially greater than what he personally owns. Similarly, as we observe below, Slim's influence on the operations of ICSS do not appear circumscribed by his want of a formal institutional title.

Finally, because we have organised our findings somewhat thematically, we have provided a timeline to clarify the chronology of events in figure 1.

\section{RESULTS \\ Slim, tobacco, ICSS and health: finance, function, influence and interests}

The relationships between ICSS, Carlos Slim and the tobacco industry remain rooted in the finances of the Slim/GC commercial enterprise and in the services to the tobacco industry that Slim continues to provide. They have been and remain arguably antithetical to national, regional and global interests in public health.

\section{Origins of ICSS funding}

Evidence from internal tobacco industry documents and web pages published at carlosslim.com (http://carlosslim.com) challenges Frenk's assertion that ICSS funds do not derive from the tobacco industry. ${ }^{18}$ The website notes that GC (originally Grupo Galas) was incorporated in 1980 'to obtain the majority stake in Cigatam, in which Philip Morris was a $29 \%$ partner'. ${ }^{38}$ While GC expanded dramatically via successive purchases in the 1980s and 1990s, the investment in Cigatam was 'the first and most important because of its cash flow, providing the Group with sufficient liquidity to capitalise on available opportunities and thereby increase its acquisitions of big companies' (emphasis added). ${ }^{39}$

By 1995 Cigatam was Mexico's most profitable domestic cigarette company, generating $24 \%$ of GC's revenue and $32 \%$ of its net income. ${ }^{40}$ In 1997, immediately before Slim was elected to its board of directors, ${ }^{41}$ the Philip Morris parent company increased its stake in Cigatam to $50 \%$, paying GC US $\$ 400$ million. ${ }^{42}$ Shortly after the inauguration of ICSS in 2007, Slim/ GC further profited by selling an additional $30 \%$ of Cigatam to PM/Altria ${ }^{43}$ at a price of US\$1.1 billion. ${ }^{44}$ By 2008, Cigatam commanded $55 \%$ of the Mexican cigarette market and continued to increase its profits. ${ }^{45} 46$ The Slim/GC enterprise continues to benefit from its remaining $20 \%$ share of Cigatam, ${ }^{44}$ as well as from holdings in PMI. ${ }^{47}$

During the early 1980s, Slim/GC also became the largest shareholder in Cigatam's main competitor, Cigarerra La Moderna (CLM), which was partnered with British American Tobacco (BAT), though seemingly less openly than was Cigatam with PM. ${ }^{38} 48$ In 1985, ostensibly 'to avoid antitrust problems', ${ }^{49}$ Slim sold his $40 \%$ stake in CLM (which then held a 75\% share of the Mexican market ${ }^{38}$ ) to competitor/colleague Alfonso Romo Garza for US\$32.4 million. ${ }^{49} 50$

The local power and profitability, as well as the attractiveness of these two Mexican companies to the international tobacco industry continued to increase. Though formally competitors, Cigatam and CLM were described as functionally cooperative, being said to constitute an effective merchandising duopoly 4951 that controlled 98\% of Mexico's cigarette market in $1997 .{ }^{52}$ In
1990, when the government of Mexico shut down the parastatal Tabacos Mexicanos (Tabamex) leaf-buying agency for reasons of corruption and incompetence (Tabamex had been established in 1972 to protect growers from cigarette manufacturers' buying practices), ${ }^{53}$ the tobacco duopoly vigorously refilled the vacuum: Cigatam's leaf-buying arm Tabacos Desvenados (Tadesa) ${ }^{54}$ together with CLM's leaf-buying division Agroindustrias La Moderna ${ }^{55}$ came to dominate the trade in Jalisco-Nayarit and Veracruz, ${ }^{53} 5657$ where $92 \%$ of Mexico's tobacco is grown. ${ }^{58}$ Philip Morris' interest in increasing its control of Cigatam and BAT's in buying CLM have both been attributed in part to this enviable control of both ends of a large and growing national market. ${ }^{51}$ When the Garza family sold its share of CLM (which it owned through Empresas La Moderna (ELM)) on to BAT in 1997, they received an astounding US\$1.7 billion 515259 : a $500 \%$ profit on their 1985 investment; thus, demonstrating the rapidly rising value of the Mexican cigarette market. Meanwhile, in 1996, the year before PM increased its stake in Cigatam to $50 \%$, ${ }^{42}$ the Mexican company contributed US\$3.4 million in license fees to Philip Morris for manufacturing Marlboro and Benson \& Hedges, and almost US\$50 million in dividend payments. $^{40}$

Slim's direct involvement in PM/Altria intensified during his service on the company's board of directors from 1997 to 2006, and he benefited additionally from annual retainers and share accumulations. ${ }^{60}$ Altria's 2005 Annual Report, the last full year in which Slim served, showed him owning over 4 million company shares, almost 1.5 times that of then-Chairman Louis Camilleri. ${ }^{60}$ In 2000 , Slim purchased 3.9 million shares at greatly depressed prices, ${ }^{61}$ selling them for a profit of US\$63 million 1 year later. ${ }^{62}$ Slim retained 1.5 million Altria shares when he retired from its board in the spring of $2006 .{ }^{63}$

Thus, while ICSS's endowment might have come immediately from shares of the telecommunications and development companies América Móvil and Ideal, ${ }^{18}$ it was profits from Cigatam/CLM/Tadesa and Slim's multiple relations with PM/ Altria that financed GC's expansion into those industries. Tobacco money enabled GC to purchase a share of the privatised Telefonos de Mexico (Telmex) from the Mexican government in 1990, which became the basis of GC telecommunications holdings, ${ }^{39} 64$ from which América Móvil was spun off in $2000 .{ }^{38}$ Ideal was similarly spun off from Grupo Financiero Inbursa in $2005,{ }^{65}$ which had functioned for CG to 'to invest and manage excise tax 'float' funds', ${ }^{40}$ that is, taxes Cigatam collected continuously from cigarette sales, but only paid over to the Mexican government periodically. PM documents and carlosslim. com web pages demonstrate that ICSS's funds originated in the tobacco industry as illustrated in figure 2 .

\section{Carlos Slim's strategic value to PM}

Documents indicate that PM viewed Slim's presence on its board as useful to its relationships in Mexico and with the Mexican-American community. When Venezuelan tobacco executive José Antonio Cordido-Freytes retired in 1994, ${ }^{66} \mathrm{PM}$ sought to fill his board position from among a list of "candidates of Hispanic origin and ... members of the outgoing cabinet of President Carlos Salinas of Mexico'. ${ }^{67}$ In 1997, after increasing its share in Cigatam, ${ }^{42}$ the Philip Morris parent company announced the election of Carlos Slim, ${ }^{41}$ hailed by then Chairman and CEO Geoffrey Bible as 'an absolutely brilliant businessman who brings to our company extensive expertise in the international marketplace'. ${ }^{41}$ A total of 46 US Hispanic elected officials, publishers, corporate heads and community activists were identified as receiving a letter from Bible calling 
Figure 2 Financial flows between Carlos Slim enterprises and transnational tobacco companies.

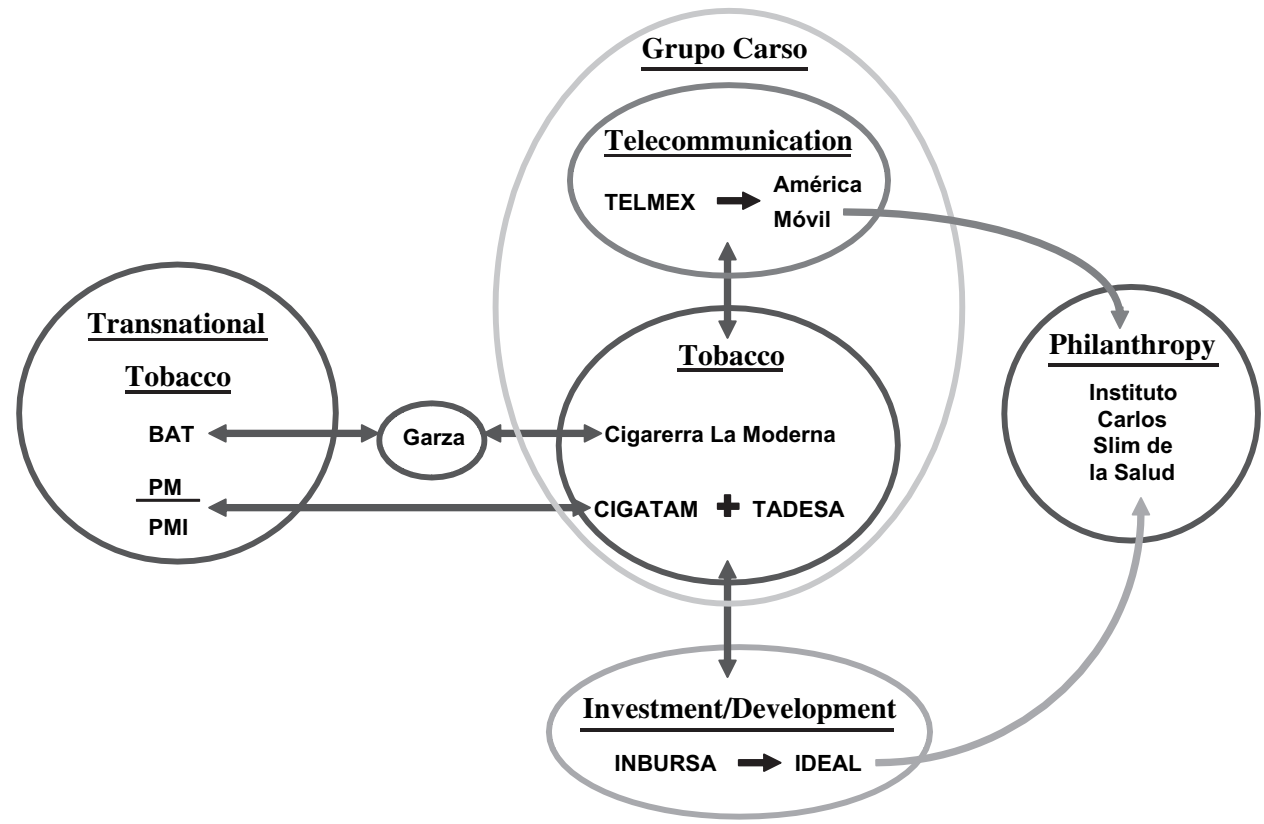

attention to Slim's appointment. ${ }^{68} 69$ Bible described Slim as bringing 'valuable insights to our company concerning the international marketplace, US-Mexican relations, and our relations with the Hispanic community, ${ }^{70}$

Even before his elevation to its board, however, Slim had been serving as a PM conduit to the Mexican government. Without a 'real corporate affairs function' in Mexico, PM had 'traditionally relied on the chairman ... of our corporate partner [that is, Slim] ... to represent us in these matters'. ${ }^{71}$ If anything, this reliance intensified: in 1999, PM's Vice Chairman for External Affairs and General Counsel Murray Bring thanked Slim for having him and his wife as personal guests and for arranging meetings with key Mexican ministers. Bring appreciated Slim's arrangement of a 'very productive and constructive' meeting with President Ernesto Zedillo and 'the opportunity to meet the Treasury and the Health Ministers at your home ... [and] to engage the Health Minister in a stimulating discussion. I can't tell you what a breath of fresh air it is to discuss important health issues with a government official who is both intelligent and open-minded'. ${ }^{72}$

Slim's value to PM was further demonstrated when the company made a substantial donation to a Slim family charity consistent with its wider 'influence' strategies. ${ }^{73}$ Shortly after the death of Slim's wife Soumaya in 1999, a Philip Morris Mexico executive recommended making a contribution in her honour to the Telmex Foundation in support of programmes she had championed. ${ }^{74}$ Bring seconded this proposal, observing it was 'consistent with [PM's] own corporate contributions' focus on food and hunger', and recommended a gift of US\$100 000 to recognise 'an active Director ... who is making, and continues to make, a significant contribution to the Company". ${ }^{75}$ Acknowledging Bible's 'concern that our contribution not appear to Carlos to be paltry', ${ }^{75}$ Bring noted this would allow them to 'advise Carlos that this is equal to the largest contribution we have ever made in these circumstances'. ${ }^{75}$

In March 2008, less than a year after the launch of the ICSS, Slim became a director for the newly independent PMI, when it was spun off from the PM/Altria parent company. ${ }^{76}$ His general directorial duties are to 'foster the long-term success of the Company ... [by] establishing broad corporate policies, setting strategic direction, and overseeing management, which is responsible for the day-to-day operations of the Company'. ${ }^{19}$ Specifically, he serves on PMI's Regulatory Affairs and Product Innovations Committee, which could be understood as a continuation of his de facto regulatory affairs services for PM/ Altria, and on the Finance Committee that makes such strategic decisions as setting the limits for corporate debt and borrowing, and setting dividend payments. ${ }^{43}$ Moreover, under New York Stock Exchange rules, among all PMI's directors, only Slim and CEO Louis Camilleri could not be considered 'independent': Slim's ownership of and executive position with Cigatam made him effectively a member of PMI management under US regulatory rules. ${ }^{19}$

\section{Who controls ICSS?}

If Slim had no further role than the financing of a health charity, it would still present a problematic case of 'white coating'-the tobacco industry clothing itself in the respectability and goodwill of medical research and healthcare provision. ${ }^{77} 78$ While Slim appears to have no official role in ICSS per se, he remains the Chairman Emeritus of GC, ${ }^{19}$ within which ICSS and its parent the Carlos Slim Foundation, are described as 'a fundamental part of Carlos Slim Helú's business strategy and culture. ${ }^{79}$ As Slim has stepped back from the day-to-day management of GC's commercial activities, he has focused more on managing its charitable foundations. ${ }^{39}$ It was over his signature that the Grupo Carso Plan 2009 reassured 'employees, clients, investors, suppliers and the general public' (our translation) that, despite difficult economic times, GC remained profitable and committed to its charitable projects, among which were detailed ICSS programmes for reducing maternal and infant mortality and increasing breast cancer awareness. ${ }^{80}$

As the public face of ICSS, Slim involves himself directly in ongoing activities at high levels. In June 2008 the First Lady of Panama met with Slim 'to sign an agreement that will allow Carso Health Institute and the government of Panama [to] implement joint actions in matter of [maternal and child] health' ${ }^{81}$ A subsequent announcement by the First Ladies of Honduras and Panama that ICSS was partnering with their Coalition to combat stigmatisation and discrimination against 
people with HIV/AIDS stated that 'Slim will support the [Coalition of] First Ladies of Latin America in its campaign against AIDS' (our translation). ${ }^{82}$

As recently as February 2010, Slim presided over the inauguration of a new Slim Initiative in Genomic Medicine, a collaboration with the joint MIT/Harvard-based Broad Institute and Mexico's National Institute of Genomic Medicine, demonstrating his 'visionary commitment to public health in Latin America ... and his interest in the improvement of health in the region' (our translation). ${ }^{83}$ While it is not possible to specify Slim's contribution to the establishment of such high-level alliances, his visible participation nonetheless remains important to the public functioning of the health charity.

Similarly, although Slim does not sit on the ICSS board of nine directors, ${ }^{84}$ only one, physician Dr Octavio Ruiz, appears not to have crosscutting relationships with Slim/GC/ICSS. Of the remaining eight, three are family members (son Marco Antonio, also CEO of Inbursa and a GC director; ${ }^{37}$ son-in-law Arturo Elias, a GC director and a key Telmex executive, ${ }^{37}$ described as Slim's spokesman ${ }^{85}$; and daughter Vanessa), a fourth is a GC executive (Raul Zepeda, a Telmex attorney and Inbursa director $^{86}$ ), two are directors of GC and/or its subsidiaries (Jose Kuri and Roberto Kriete ${ }^{86}$ ), the seventh, Dr Guillermo Palacios y Santos, received the 2009 'Carlos Slim Prize for a Research Career' (our translation) worth US $\$ 100000,{ }^{87}$ and the eighth, Dr Roberto Tapia-Conyer, is employed by ICSS as its director general. ${ }^{88}$ Moreover, as a senior figure in the Mexican Health Ministry, Tapia-Conyer publicly defended the Ministry's 2004 concessions to Cigatam, PM and BAT made in exchange for their payments to the national social security programme. ${ }^{89}$ As part of the agreement made by then Health Minister Julio Frenk, Mexico waived its authority to regulate details of advertising and cigarette package design, including agreeing no graphic warnings, and effectively undertook that future tax increase or tobacco control regulation would not financially harm the companies. ${ }^{90}$ This agreement was reached on WHO World No Tobacco Day (31 May), ${ }^{91}$ and arguably breached Mexico's commitments under the FCTC, ${ }^{90}$ which Mexico had become the first country in the Americas to ratify only 3 days earlier. ${ }^{92}$ Criticised vociferously by public health advocates in Mexico and abroad, the agreement was not renewed by the new government in $2006 .^{93}$

Finally, it cannot be overemphasised that Slim, who is said to remain in close communication with his three sons and two sons-in-law, ${ }^{94}$ the active managers of his business interests, ${ }^{37}$ is not simply any wealthy patron. His family holdings were reported to comprise more than 5\% of Mexico's 2006 gross domestic product and to account for one-third the value on Mexico's US $\$ 422$ billion stock exchange. ${ }^{14}$ Consistently ranked alongside Bill Gates and Warren Buffett as one of the three richest men in the world, ${ }^{14-17}$ Slim's significance within a national economy $1 / 14$ th the size of the US ${ }^{95}$ substantially exceeds that of Buffett and Gates.

\section{ICSS and the health consequences of tobacco}

Global mortality attributable to tobacco is staggering in its scale and increasingly inequitable in its distribution. Total deaths are expected to rise from 5.4 million in 2005 to 8.3 million in 2030, by which point they are projected to decline in high income countries by $9 \%$ while doubling from 3.4 million to 6.8 million across low-income and middle-income countries. ${ }^{96}$ It is clear that globalisation is contributing to this shift, with the World Bank having concluded that trade liberalisation 'has a large and significant impact on smoking in low-income countries, and a smaller, but still important effect on smoking in middleincome countries, while having no effect on higher income countries'. 97

Following 2008 population estimates, Mexico ranked 15th in the world in terms of number of male smokers (11.3 million $)^{98}$ and 19 th in terms of female smokers (3.8 million): $:^{98} 15 \%$ to $20 \%$ of male deaths and $5 \%$ to $10 \%$ of female deaths in 2000 were thought attributable to smoking. ${ }^{98}$ As ICSS was launched to 'prioritise work on ... emerging diseases, such as heart disease, cancer, and other chronic and degenerative diseases, as well as ... challenges due to the globalisation of health risks', ${ }^{13}$ all characteristic consequences of tobacco smoking, it is reasonable to ask what ICSS says and does about the subject.

Neither tabaco (tobacco) nor cigarrillo (cigarette) are indexed on the ICSS website. Fumar (smoking) and dejar de fumar (smoking cessation) are each indexed once and lead to the same web page described below. Tabaquismo (tobacco addiction) is indexed twice: the first reference is that which also indexes dejar de fumar.

The principle reference to smoking is presented under a programme titled Vive Sano ('Live Healthy'), described as 'an innovative strategy intended to promote behavioural changes through the adoption of healthier lifestyles'. Tabaquismo is sandwiched between 'sedentarism' and 'excessive consumption of fats and carbohydrates', referred to as 'risks of suffering noncommunicable diseases', and the focus of the programme given as an 'emphasis on diabetes, hypertension and obesity' (our translations). ${ }^{99}$

Vive Sano comprises five 'objectives': (1) 'raising public awareness ... [through] healthful messages'; (2) 'motivating people to adopt and maintain healthy lifestyles ... through strategies ... which endorse healthy eating, physical activity and smoking cessation'; (3) 'offering quality outpatient medical attention'; (4) 'using new communication technologies to support health education and promotion'; (5) 'educating, assisting and supporting self-care and monitoring by people with risk factors ... and their families' (our translations). ${ }^{100}$ Already Vive Sano seems weak, but its inadequacy from a tobacco control perspective emerges starkly when it is compared to the best practice recommendations of, for example, the US Center for Disease Control and Prevention; to wit: 'preventing initiation among youth and young adults; promoting quitting among adults and youth; eliminating exposure to secondhand smoke; identifying and eliminating tobacco-related disparities among population groups'. ${ }^{101}$ Vive Sano makes no mention of youths, initiation prevention, elimination of secondhand smoke, or issues of population disparities, and its acknowledgement of cessation is vague at best. Compounding silence with misdirection, Vive Sano's 'objectives' are illustrated with a frankly erotic photograph of a young woman in lycra shorts measuring the circumference of her well-toned thigh. ${ }^{100}$

The one additional index of tabaquismo on ICSS's web site-a 2008 press release announcing ICSS's cosponsorship of a Healthful Longevity programme in Pacheco, state of Hidalgomentions youth and health resource-deprived populations but only in the context of 'treating chronic illnesses in the population of limited resources and identifying risk factors among youth'. Located in a diabetes centre, Healthful Longevity 'is focused on evaluation of the state of health of healthy people and people with risk factors for four diseases: diabetes, obesity, hypertension and elevated cholesterol and triglycerides'. Again, tabaquismo is simply sandwiched between 'overweight' and 'sedentarism' as a 'risk factor' (our translations) ${ }^{102}$ with no elaboration of causes, consequences or remedies. The 2 web 
indexings for tabaquismo contrast with a total of 20 combined returns for obesidad (obesity) and sobrepeso (overweight).

\section{DISCUSSION}

ICSS's funding from telecommunication and infrastructure shares ultimately derives from the tobacco industry. By Slim's account, it was the large cash flows generated by cigarette manufacturing, and by our analysis, additional profits from shares in domestic and transnational tobacco companies that financed GC's expansion into these other sectors.

Frenk responded to Chapman's critique of ICSS being funded by a tobacco magnate by accusing him of applying double standards: 'A significant number of foundations, universities, and other civic organisations in rich countries have been established thanks to fortunes that were entirely or mostly derived from tobacco' ${ }^{18}$ But the tobacco links at play here are not matters of ancient history: GC, which parents the Carlos Slim Foundation of which ICSS is a subsidiary, retains a $20 \%$ share in the pre-eminent tobacco company in the largest market in Spanishspeaking America, ${ }^{103}$ and Slim and his family have benefited from owning large volumes of shares in Altria and PMI. Slim's involvement in the current fortunes of PMI is shown by his designation as effectively a member of management under New York Stock Exchange rules. By serving PMI, the founder of what would be Latin America's most influential health charity has agreed to promote the long-term interests of the world's leading tobacco transnational.

The profits, power and prestige of Slim, his family and GC are substantially derived from selling cigarettes; their ongoing engagement in this business suggests their continued acceptance of this activity as unproblematic. Using 'tobacco money' to address pressing regional health needs, even when 'diluted' by other revenue streams, publicly reinforces this perception.

Conflict of interest can be defined as competition between private/personal interests and those specific to a position of trust, ${ }^{104}$ and resides in the structure of situations as much as in the inclinations of individuals. ${ }^{105}$ Recognising that conflicts of interest arising from relationships with the commercial sector could jeopardise trust in the decision-making process and the integrity of decisions, WHO requires consultants to disclose not only overt interests 'that could unduly influence the expert's position', but also apparent interests that 'could result in the expert's objectivity being questioned by others' and potential interests 'which any reasonable person could be uncertain whether or not should be reported'. ${ }^{106}$ These are internal guidelines formally binding only on the WHO itself. Nonetheless, being so well informed by the history of tobacco industry interference in health policy, they might stand as model for governments and other actors facing these issues.

While some degree of conflict of interest may be inescapable in public-private collaborations, ${ }^{104}$ the potential for conflicts is exacerbated by lack of transparency, ${ }^{107}$ and heightened by the appearance of deceit and/or manipulation. ${ }^{108}$ The Committee of Experts on Tobacco Industry Documents identified precisely these elements in tobacco industry activities, concluding that: 'the role of tobacco industry officials ... was often concealed ... hid[den] behind a variety of ostensibly independent quasiacademic, public policy, and business organisations whose tobacco industry funding was not disclosed ... relying heavily on international and scientific experts with hidden financial ties to the industry ... quietly influence[ing] other UN agencies and representatives of developing countries to resist WHO's tobacco control initiatives'. ${ }^{109}$
In 2009, a report produced in conjunction with the Third Conference of FCTC Parties (COP3), examined ongoing tobacco industry interference in Southeast Asian health policymaking, ${ }^{110}$ while WHO updated its general tobacco industry interference observations as well. ${ }^{111}$

The tobacco industry stratagems we have noted-turning other UN agencies and developing countries against WHO tobacco control initiatives, ${ }^{109}$ making payments to Mexico's Seguridad Social in lieu of stricter national legislation ${ }^{90}$ and alternating between carrot and stick approaches to financing academic medical research ${ }^{78}$ - fall into a common pattern of using of cash to buy legitimacy and influence institutional and public policy while generally concealing industry interest and presence behind third parties or closed doors. Hence, the World Health Assembly caution regarding tobacco industry influences on WHO delegations, ${ }^{112}$ the singling out of the tobacco industry in WHO's disclosure requirements, ${ }^{106}$ and the specific crafting of FCTC Article 5.3 in response. ${ }^{23}$

The fundamental conflicts identified here, passed over by ICSS without acknowledgement or proposed mitigation, already suggest that the organisation is ill suited to addressing the health challenges that it has undertaken. ICSS claims commitment to combating health risks arising from globalisation, ${ }^{7} 13$ yet tobacco use is the foremost cause of preventable deaths worldwide ${ }^{113}$ and the primary vector of the tobacco pandemic is a global industry led by PMI and BAT with the collaboration of regional partners like Cigatam and CLM. ${ }^{114} 115$

Frenk's defence of ICSS concludes with a call for 'serious research' into the financing of foundations by harmful industries, and the subsequent generation of guidelines 'to promote transparent and ethical behaviour from all parties, in a way that places the pursuit of health equity as the supreme value'. ${ }^{18}$ In the case of tobacco, the industry's record of malfeasance in undermining health policy is well established, compounding the intrinsic conflicts between public health and corporate interests. $^{78} 90$ 109-111 116117 ICSS expanding presence at the heart of Mexican and more broadly Latin American health policymaking and provision, ${ }^{2-6}$ and its strategic connections, notably through its founding Executive President Dr Julio Frenk, to the Clinton Global Initiative, ${ }^{3} 12118$ the Gates Foundation, ${ }^{5} 6$ the Harvard School of Public Health, ${ }^{12}$ the Harvard/MIT-based Broad Institute, ${ }^{83}$ Seattle's Fred Hutchinson Cancer Research Centre ${ }^{119}$ and other philanthropic and research institutions at the heart of international public health affairs mean that the impacts of ICSS actions will likely grow in consequence.

Tobacco industry threats to public health are specifically recognised in the WHO FCTC Article 5.3, requiring states to protect their public health policies from tobacco industry interference. The recently published implementation guidelines for this article explicitly state that:

Parties should not allow acceptance by any branch of government or the public sector of political, social, financial, educational, community or other contributions from the tobacco industry or from those working to further its interests, except for compensations due to legal settlements or mandated by law or legally binding and enforceable agreements. ${ }^{23}$

On the basis of the evidence presented here, these guidelines immediately put in question the legitimacy of working with ICSS by the Governments of Mexico and Spain or their agencies.

While these guidelines formally speak to the responsibilities of signatory governments, it is not unreasonable to suggest that their spirit should be honoured by the health-oriented NGOs, research institutions and charities who partner with committed 


\section{What this paper adds}

Although tobacco industry connections were not mentioned in initial reports of the inauguration of the Instituto Carlos Slim de la Salud (ICSS), ${ }^{73}$ they were soon reported by then Tobacco Control editor Simon Chapman. He noted the close connections of ICSS's founder Carlos Slim with Philip Morris (PM) and Slim's ownership stake in the PM Mexican subsidiary Cigatam and criticised 10 prominent health and development figures who had leant their names to the institute for violating the spirit of the WHO Framework Convention on Tobacco Control (FCTC). ${ }^{20}{ }^{21}$ Recently Chapman has argued that a new collaboration with ICSS involving the Bill and Melinda Gates foundation is similarly problematic. ${ }^{124}$

- This paper provides detailed documentation and extends understanding of the complex relationships between ICSS, Slim and the tobacco industry based on examination of tobacco industry documents, financial filings and Slim, ICSS, industry and related websites and publications. It demonstrates that Slim remains an important tobacco company protagonist on the Mexican and international stages and that it is difficult to separate his tobacco-based earnings from ICSS's ostensibly tobacco-free funding. This creates a prima facie conflict of interest between ICSS's agenda to shape Latin-American health policy and research regarding the health consequences of globalisation and the sale of a product that is the leading cause of premature mortality and morbidity worldwide. With reference to the FCTC and WHO's institutional efforts to manage such conflicts, the paper concludes that increased interaction between international health agencies and the commercial sector demands the development of more robust institutional policies and practice to protect against potential conflicts of interest.

governments. In a recent case involving the Canadian International Development Research Centre (IDRC), the African Tobacco Control Alliance and the Gates Foundation, donors and beneficiaries acted to end an ethically troubling collaboration, showing that it is possible to 'do the right thing' even if after the fact. ${ }^{120}$ In this instance, when cyberjournalist Philippe Boucher published his 'discovery' that the IDRC Board Chair was simultaneously a director of Imperial Tobacco Canada, ${ }^{121}$ African Tobacco Control Alliance withdrew as cohost of a planned PanAfrican tobacco control conference and congratulated the Gates Foundation for withdrawing its cosponsorship. ${ }^{122}$ The foundation further demonstrated conscientiousness by terminating a large support grant to IDRC on the grounds of conflict of interest. ${ }^{123}$ It remains to be seen whether such convictions will be consistently applied via a refusal to collaborate with the ICSS, an act which would offer an important example to the International Development Bank and to FCTC parties including Spain as has recently been called for in Lancet by Chapman. ${ }^{124}$

\section{CONCLUSIONS}

As the authors of Global Health Watch 2 wrote: '[I]t matters if philanthropic spending is based on wealth that has been accumulated unethically' ${ }^{125}$ While the implications of this observation hardly end with the tobacco industry, tobacco can, at the very least, be presented as a defining example. Despite international agencies' increasing strategic engagement with and reliance upon the commercial sector, ${ }^{126}$ the attention given to the terms of such engagement has been strikingly inadequate. Reviews of governance arrangements for global health initiatives have consistently identified the inadequate attention paid to the screening of corporate partners and the management of potential conflicts of interest. ${ }^{127} 128$ A review of 18 public-private infectious disease partnerships found that only 4 undertook screening of potential partners, ${ }^{128} 129$ and 1 reported informally that it would 'accept donations from donors with poor social responsibility, "but we are going to be expensive". ${ }^{128}$ Another report similarly found that, 'influential actors, both within and outside WHO ... regarded the very concept of conflict of interest as an obstacle to new and closer engagements with industry' ${ }^{130}$ Such findings highlight the need for a comprehensive review of WHO's Guidelines on working with the commercial sector to achieve health outcomes, ${ }^{131}$ a need insufficiently addressed by the WHO Secretariat's recent report on partnerships. ${ }^{132}$

ICSS can reasonably be viewed as essentially the tobaccofunded gift of one of the world's richest men. Its emergence as a significant force aimed at shaping the public health agenda of a continent therefore makes urgent the need for a broader debate about the role of corporate philanthropy in international health.

Acknowledgements The authors wish to thank Stanton Glantz for his thorough reading and useful comments on an earlier version of this manuscript. They also wish thank reviewers Stella Bialous, Simon Chapman and Pascal Diethelm for their careful reading and numerous helpful comments.

Funding This paper was supported by a University of Edinburgh Tobacco Control Research Group fellowship and by US National Cancer Institute grant 2 R01 CA091021-09

\section{Competing interests None.}

Contributors The paper was based on the MSc dissertation titled 'Tobacco, philanthropy, and conflict of interest: Assessing the Carso Health Institute' by TB, who undertook the bulk of the industry document research. TB wrote the first draft of the subsequent paper. NW added research on Carlos Slim and his finances, the tobacco industry in Mexico, and the operations of the Instituto Carlos Slim de la Salud: NW led the writing of subsequent drafts. JC suggested and supervised the original dissertation and contributed substantially to the writing of the paper.

Provenance and peer review Not commissioned; externally peer reviewed.

\section{REFERENCES}

1. FG. Inauguran Centro de Salud. 2007. http://noesfecalandia.blogspot.com/ 2007 09_01_archive.html (accessed 9 Nov 2007)

2. International AIDS Society. XVII International AIDS conference sponsors and supporters. 2008. http://www.aids2008.org/mainpage.aspx?pageld =8 (accessed 23 Aug 2008).

3. Clinton Global Initiative. Member commitments: Cancer de Mama en América Latina. 2008. 2008. http://www.clintonglobalinitiative.org/NETCOMMUNITY/Page. aspx?pid $=2646 \& q=302466 \& n=x$ (accessed 31 Mar 2008).

4. Bliss KE. Health in Latin America and the Caribbean Challenges and Opportunities for US Engagement. Washington, DC: Center for Strategic and International Studies, 2009.

5. Inter-American Development Bank. Bill \& Melinda Gates Foundation, Carlos Slim Health Institute, Spain, and the IDB collaborate to improve health of the poor in Mesoamerica. 2010. http://www.iadb.org/news-releases/2010-06/english/bill-andmelinda-gates-foundation-carlos-slim-health-institute-spain-and-the-idb-7317.html (accessed 16 Jun 2010)

6. Instituto Carlos Slim de la Salud. Iniciativa Salud Mesoamérica. 2015. 2010. http://www.salud.carlosslim.org/nuestrosprogramas/Paginas/SaludMeso2015.aspx (accessed 12 Aug 2010).

7. Braine T. Mexican billionaire invests millions in Latin American health. Bull World Health Organ 2007;85:574-5.

8. Instituto Carlos Slim de la Salud. Inicio, Instituto Carlos Slim de la Salud. 2010. http://www.salud.carlosslim.org/Paginas/homeCarso.aspx\# (accessed 9 Aug 2010).

9. Instituto Carlos Slim de la Salud. Comité Asesor Internacional, Síntesis Curricular, Julio Frenk Mora, 2009. http://www.salud.carlosslim.org/quienessomos/ Documents/Julio\%20Frenk\%20Mora.pdf (accessed 9 Aug 2009).

10. Global Health Council. World Health Organization Director-General Search. 2003. http://www.globalhealth.org/view_top.php3?id=196 (accessed 12 Aug 2003).

11. Glusker A. Who will lead WHO? BMJ 2006;333:938. 
12. Harvard School of Public Health. Office of the Dean, Julio Frenk, Dean, Biography. 2010. http://www.hsph.harvard.edu/administrative-offices/deans-office/ julio-frenk-dean/ (accessed 9 Aug 2010).

13. Alleyne G, Aninat E, de Ferranti D, et al. Instituto Carso de la Salud: a boost for health philanthropy. Lancet 2008;371:100-1

14. Shankar V, Arai A. Mexico's Slim Passes Bill Gates to Be World's Richest (Update1). 2007. http://www.bloomberg.com/apps/news?pid=20601086\&sid= alTFONAKumvl (accessed 13 Nov 2007)

15. Miller M. Gates no longer world's richest man. 2008. http://www.forbes.com/ 2008/03/05/buffett-worlds-richest-cx mm 0229buffetrichest.html laccessed 5 Nov 2008).

16. Kroll L, Miller M, Serafin T. The World's Billionaires. 2009. http://www.forbes.com/ 2009/03/11/worlds-richest-people-billionaires-2009-billionaires-intro.html laccessed 23 Aug 2009).

17. Miller M, Kroll L. Bill Gates no longer World's Richest Man. 2010. http://www. forbes.com/2010/03/09/worlds-richest-people-slim-gates-buffett-billionaires-2010intro.html (accessed 23 Aug 2010)

18. Frenk J. Response from Group Carso de la Salud. Lancet 2008;371:1243-44.

19. Camilleri L. [Information statement mailed to all Altria stockholders, describing the spin-off in detail and containing important information, including financia statements, about PMI]. 2008. http://phx.corporate-ir.net/External.File? item $=$ UGFyZW50SU09MzMwNTd802hpbGRJRD0tMXxUeXBIPTM $=q \mathrm{t}=1$ (accessed 21 Jan 2008)

20. Chapman S. Group Carso, health philanthropy, and tobacco. Lancet 2008;371:1243.

21. Chapman S. International tobacco control should repudiate Jekyll and Hyde health philanthropy. Tob Control 2008;17:1.

22. World Health Organization. WHO framework convention on tobacco control Geneva: WHO Press, 2003

23. World Health Organization. Guidelines for implementation of Article 5.3 of the WHO Framework Convention on Tobacco Control on the protection of public health policies with respect to tobacco control from commercial and other vested interests of the tobacco industry. 2009. http://www.who.int/fctc/guidelines/article_5_3.pdf (accessed 3 Nov 2009).

24. Chapman S. Unpublished Chapman reply to Frenk in Lancet. 2008. http://tobacco. health.usyd.edu.au/assets/pdfs/tobacco-related-papers/FrenkReply.pdf laccessed 2008).

25. Carter SM. Tobacco document research reporting. Tobacco Control 2005; 14:368-76

26. Bero L. Implications of the tobacco industry documents for public health and policy Annu Rev Public Health 2003;24:267-88.

27. Hurt RD, Ebbert JO, Muggli ME, et al. Open doorway to truth: legacy of the Minnesota tobacco trial. Mayo Clin Proc 2009;84:446-56.

28. National Association of Attorneys General. Master settlement agreement, 1998. http://www.naag.org/backpages/naag/tobacco/msa (accessed 2 Sep 1998)

29. United States of America et al., v. Philip Morris USA, Inc. (f/k/a Philip 3 Morris, Inc.). United States District Court for the District of Columbia, Civil Action No. 99-2496. 2006

30. MacKenzie R, Collin J, Lee K. The tobacco industry documents: An introductory handbook and resource guide for researchers. 2003. http://www.Ishtm.ac.uk/cgch/ tobacco/Handbook\%2008.07.03.pdf (accessed 21 Jul 2003).

31. Forster N. The analysis of company documentation. In: Cassell C, Symon G, eds. Qualitative Methods in Organizational Research A Practical Guide. London: Sage, 1995.

32. Hill MR. Archival Strategies and Techniques. London: Sage, 1993.

33. Guardino SD, Friedman LC, Daynard RA. Remedies for document destruction: Tales from the tobacco wars. Virginia Journal of Social Policy \& the Law 2004; 12:1-60

34. Chan FM. Insiders slim down on hot Altria stocks. 2005. http://online.barrons.com/ article/SB113379793058414086.html?mod=9_0030_b_online_exclusives_left (accessed 10 Nov 2005)

35. EDGAR Online. INMOBILIARIA CARSO S A DE C V: Declared Holdings. 2009 http://biz.yahoo.com/t/00/6991.html (accessed 11 Nov 2009).

36. Bronco Drilling Company Inc. Form DEF 14A Bronco Drilling Company, Inc. 2009. http://scottsdale.brand.edgar-online.com/displayfilinginfo.aspx? FilingID=6832381-878-157341\&type $=$ sect\&Tablndex $=2 \&$ companyid $=675749 \& p p u=$ \%252fdefault.aspx\%253fcompanyid\%253d675749 (accessed 2009).

37. Grupo Carso. Grupo Carso Annual Report, 2008. 2008. http://www.gcarso.com mx/NR/rdonlyres/D257AE32-CB7B-4D8B-A268-7FBCA6AE75D8/0/ GC ENG InfoAnual 2008.pdf (accessed 2008).

38. Slim Helú C. Carlos Slim Helú Business activity. 2008. http://www.carlosslim.com/ act empresarial ing.html (accessed 28 Apr 2008)

39. Slim Helú C. Cärlos Slim Helú Biography. 2008. http://www.carlosslim.com/ biografia ing.html (accessed 5 Aug 2008).

40. [Philip Morris]. Carlos Slim Notes on Slim and PMI Relationships. Jan [1996], 2000. Philip Morris. http://legacy.library.ucsf.edu/tid/kcn85c00.

41. [Philip Morris Companies Inc.]. Carlos Slim Elected to Board of Directors of Philip Morris Companies Inc [Confidential draft]. 27 Aug 1997. Philip Morris. http:// legacy.library.ucsf.edu/tid/wu037c00.

42. Grupo Carso, Philip Morris International. Philip Morris and Grupo Carso Strengthen Mexican Cigarette Alliance. 25 Jun 1997. Philip Morris. http://legacy. library.ucsf.edu/tid/hwn85c00
43. Philip Morris International. 2009 Annual Report. 2010. http://www.viewer.iversion.com/?id=4RACNP74H6P (accessed 10 Aug 2010).

44. Reuters. Mexico's Carso net soars on Philip Morris sale. 2008. http://uk.reuters. com/article/idUKN2650728520080226 (accessed 12 Aug 2008).

45. Burritt C. Philip Morris net tops estimates on Indonesia, Mexico (Update3). 2008. http://www.bloomberg.com/apps/news?pid=newsarchivegsid=aoHclOCY003k (accessed 23 Jul 2008).

46. Overstreet R. Mexican officials deliver a one-two punch. 2008. http://www tobaccojournal.com/Mexican officials deliver a one-two punch.49072.0.htm (accessed 7 Jul 2008)

47. Philip Morris International. United States Securities and Exchange Commission, Form 4, Statement of Changes in Beneficial Ownership. 2008. http://investors.pmi. $\mathrm{com} /$ phoenix.zhtml?c=146476\&p=irol-sec\&secCat01Enhanced.1_rs $=181 \& \mathrm{sec}$ Cat01Enhanced. $1 \mathrm{rc}=10 \mathrm{\&}$ control searchbox $=$ \&control selectgroup $=5 \&$ control symbol $=$ (accessed 2 Feb 2008)

48. Johnson A, Crichton, Fuelwell J. Acquisition of almost $30 \%$ of ELM shares by Carlos Slim [Note for the Tobacco Executive Committee of British American Tobacco]. 1983. British American Tobacco. http://legacy.library.ucsf.edu/tid/ beh20a99.

49. Smith G. The star behind Mexico's pulsar in the midst of a bitter recession, Alfonso Romo is going global. 1996. http://www.businessweek.com/archives/1996/ b3469093.arc.htm (accessed 1 Apr 1996).

50. Heywood DG, Fulwell J, Crichton RAC. Minutes of the Tobacco Executive Committee meeting held on 5th February 1985. 5 Feb 1985. British American Tobacco. http://legacy.library.ucsf.edu/tid/jmw38a99.

51. Hammond R. Country Case Studies Addicted to Profit: Big Tobacco's Expanding Global Reach. 10 Feb 1999. Philip Morris. http://legacy.library.ucsf.edu/tid/ uzp84a00.

52. [RJ Reynolds]. Appendices. Market Summary. Mexico. Overview. 17 Feb [1997], 1999. RJ Reynolds. http://legacy.library.ucsf.edu/tid/gnn20d00.

53. Runsten D. Globalization, NAFTA and the Restructuring of Mexican Food Processing: Consequences for Small Producers. 2003. ftp://ftp.fao.org/es/esn/ food systems/runstenF.pdf (accessed 2003).

54. [Philip Morris]. Mexican leaf growing program. Jun 1992. Philip Morris. http:// legacy.library.ucsf.edu/tid/ryg38d00.

55. Alvarez SS, Díaz Romo P. Globalization, Migration and Child Labour: the case of girl and boy day labourers in tobacco fields in Nayarit, México. 1999. http://www. huicholesyplaguicidas.org/huichol_cas/cont/docs/glob_migra_en.pdf laccessed 10 Dec 1999).

56. Léonard E, Mackinlay $H$. Transferts public/privé et appropriation collective La privatisation du monopole public TABAMEX au Mexique. 2003. http://afm.cirad.fr/ documents/3 Organisations/ActionCollective/FR/AC Leonard.pdf (accessed 2003)

57. Mackinlay $\overline{\mathbf{H}}$. Nuevas tendencias en la agricola de contrato: los productores de tabaco en Nayarit despues de la privitacion de Tabamex (1990-1997). In: Grammont HC, ed. Empresas Reestructuración Productiva Y Empleo En La Agricultura Mexicana. Mexico City, MX: Plaza y Valdes, 1999:145-204.

58. Waters H, Sáenz de Miera B, Ross H, Reynales Shigematsu LM. The economics of tobacco and tobacco taxation in Mexico. 2010. http://tobaccofreecenter.org/files/ pdfs/en/Mexico tobacco_taxes_report_en.pdf (accessed 2010).

59. Slim Helú C. Carlos Slim Helú informātion, events questions and answers. 2007. http://www.carlosslim.com/03 ing.html (accessed 28 Apr 2007).

60. Altria Group. United States Securities and exchange Commission, Schedule 14A Proxy Statement Pursuant to Section 14(a) of the Securities Exchange Act of 1934 2005. http://www.sec.gov/Archives/edgar/data/764180/000119312505049450/ ddef14a.htm\#toc46723 12 (accessed 1 Dec 2005).

61. [Bloomberg News], Omgikas. Mexico's Slim Buys $\$ 90$ Min of Philip Morris Shares. 21 Jan 2000. Philip Morris. http://legacy.library.ucsf.edu/tid/gjz35c00.

62. Moody J. Mexico's Slim Finds Contrarian Investment Gamble Pays (Update2). 11 Dec 2000. Philip Morris. http://legacy.library.ucsf.edu/tid/zum49c00.

63. Altria Group. Compensation of directors. 2006. http://google.brand.edgar-online com/EFX dll/EDGARpro dll?FetchFilingHtmlSection1?SectionID=4273876-6733378278\&SessionID = Yj5HC9JmyT2Hs7 (accessed 1 Dec 2006).

64. Mehta SN. Carlos Slim, the richest man in the world. 2007. http://money.cnn.com/ 2007/08/03/news/international/carlosslim.fortune/ (accessed 20 Aug 2007).

65. IDEAL. History. 2007. http://www.ideal.com.mx/site/index.php? option $=$ com content\&task $=$ view \&id $=17$ \&ltemid $=81$ (accessed 15 Aug 2007)

66. Barlett DT. [Letter to Richard Jose Bela concerning Hispanic executives at Philip Morris]. 27 Oct 1994. Philip Morris. http://legacy.library.ucsf.edu/tid/fod66c00.

67. Bartlett DT. [October 26, 1994 minutes of the Board of Directors of Philip Morris Companies Inc.]. 26 Oct 1994. Philip Morris. http://legacy.library.ucsf.edu/tid/ qkq92e00.

68. Holsenbeck GP. Carlos Slim Helu. 25 Aug 1997. Philip Morris. http://legacy.library. ucsf.edu/tid/nho80c00.

69. [Philip Morris]. Persons to Receive Bible Letter on Carlos Slim. Aug 1997. Philip Morris. http://legacy.library.ucsf.edu/tid/xcn85c00.

70. [Bible GC]. [Draft letter to National Council of La Raza President Raul Yzaguirre announcing appointment of Carlos Slim to Philip Morris Board of Directors]. 26 Aug 1997. Philip Morris. http://legacy.library.ucsf.edu/tid/wcn85c00

71. Berlind M. 4 Latin America Issues. 17 Jul 1997. Philip Morris. http://legacy.library ucsf.edu/tid/lxo63c00.

72. Bring MH. [Thank you letter to Carlos Slim regarding visit in Mexico]. 25 Mar 1999. Philip Morris. http://legacy.library.ucsf.edu/tid/cpm62c00 
73. Tesler LE, Malone RE. Corporate Philanthropy, Lobbying, and Public Health Policy. Am J Public Health 2008;98:2123-33.

74. [Espinosa de los Reyes F], Delosreyes FE. Facsimile Cover Sheet [Recommendations regarding contribution in memory of Soumaya Slim]. 09 Mar 1999. Philip Morris. http://legacy.library.ucsf.edu/tid/dpm62c00.

75. Bring MH. Charitable Contribution in Honor of Mrs Slim. 26 Mar 1999. Philip Morris. http://legacy.library.ucsf.edu/tid/djg80c00.

76. Philip Morris International. Remarks for investor presentation by Louis C. Camilleri. 2008. http://www.pmi.com/eng/media center/speeches and presentations/ pages/remarks_for_investor_presentation_by_louis_c_camilleri_20080311.aspx (accessed 23 Aug 2008 ).

77. Wander N. The tobacco industry is the problem: response to Thomas Jue. 2007. http://www.sciencemag.org/cgi/eletters/315/5814/937b (accessed 1 May 2007).

78. Wander N, Malone RE. Selling off or selling out? Medical schools and ethical leadership in tobacco stock divestment. Acad Med 2004;79:1017-26.

79. Slim Helú C. Carlos Slim Helú social activity. 2008. http://carlosslim.com/ responsabilidad ing.html (accessed 5 Aug 2008).

80. Slim Helú C. Grupo Carso Plan 2009. 2009. http://www.carlosslim.com/ slimcomunicado.pdf (accessed 10 Nov 2009).

81. Instituto Carso Salud. Mrs. Vivan Fernandez de Torrijos, First Lady of Panama and Engineer Carlos Slim Helu, signed today an agreement to apply maternal and infant health programs in that country, through the Carso Health Institute (CHI). 2008. http://www.carlosslim.com/responsabilidad ics ing.html (accessed 14 Apr 2008).

82. EFE. Slim apoyará a las primeras damas de América Latina en su campaña contra el sida. Medicina Digital. 20 0ct 2008. http://www.medicinadigital.com/index.php/ información-general/10834-slim-apoyar-las-primeras-damas-de-amca-latina-en-sucampaontra-el-sida.html (accessed 1 Nov 2010)

83. Instituto Carlos Slim de la Salud. Iniciativa Slim en Medicina Genómica. 2010. http://www.salud.carlosslim.org/nuestrosprogramas/Paginas/ PubllnicMediGeno 01.aspx (accessed 9 Aug 2010).

84. Instituto Carso de la Salud. Instituto Carso de la Salud Consejo Directivo. 2009. http://www.salud.carlosslim.org/quienessomos/Paginas/ConsejoDirectivo.aspx (accessed 23 Aug 2009)

85. Lacey M. Carlos Slim Helú: The Reticent Media Baron. 2009. http://www.nytimes. com/2009/02/16/business/media/16slim.html (accessed 23 Aug 2009).

86. Grupo Carso. Grupo Carso Annual Report 2007. 2008. http://www.gcarso.com $\mathrm{mx} / \mathrm{NR} /$ rdonlyres/./GC ENG AnnualReport 2007.pdf (accessed 2008).

87. Instituto Carlos Slim de Ta Salud. Premio Carlos Slim en Salud. 2010. http:// 201.116.23.233:81/convocatorias/Antiguos/Documents/Nideo Premios/NideoAll. html (accessed 29 Apr 2010).

88. Instituto Carlos Slim de la Salud. Dirección General. 2009. http://201.116.23 233:81/quienessomos/Paginas/DireccionGeneral1.aspx (accessed 29 Apr 2009).

89. Tapia-Conyer R, Ruíz-Gaytán C, Caso-González L. Mexico and the tobacco industry: Response from the Ministry of Health. BMJ 2006;332:548.

90. Samet J, Wipfli $\mathrm{H}$, Perez-Padilla $\mathrm{R}$, et al. Mexico and the tobacco industry: doing the wrong thing for the right reason? BMJ 2006;332:353-4.

91. Presidencia de la Republica de Mexico. Aportará la industria tabacalera 4 mil millones de pesos para el sistema de salud. 2004. http://fox.presidencia.gob.mx/ buenasnoticias/salud/?contenido=8281 \&pagina $=21$ (accessed 11 Aug 2004)

92. Pan American Health Organization. WHO Framework Convention on Tobacco Control (WHO FCTC). 2010. http://www.paho.org/english/ad/sde/ra/tobframework. $\mathrm{htm}$ \#Signatories\%20and\%20Ratifications (accessed 11 Aug 2010).

93. Tobacco Facts. Mexico Tobacco Control Policy: Federal. 2009. http://www. tobacco-facts.net/2009/09/mexico-tobacco-control-policy-federal laccessed $17 \mathrm{Mar}$ 2009).

94. Quinn J. Profile: Carlos Slim. 2009. http://www.telegraph.co.uk/news/newstopics/ profiles/4317646/Profile-Carlos-Slim.html (accessed 23 Aug 2009).

95. International Monetary Fund. World economic and financial surveys world economic outlook database. 2009. http://imf.org/external/pubs/tt/weo/2009/02/ weodata/index.aspx (accessed 12 Nov 2009).

96. Mathers C Loncar D. Projections of global mortality and burden of disease from 2002 to 2030. PLoS Med 2006;3:e442.

97. Taylor A, Chaloupka F, Gundon E, et al. The impact of trade liberalization on tobacco consumption. In: Jha P, Chaloupka F, eds. Tobacco Control in Developing Countries. Oxford: Oxford University Press, 2000: 343-64.

98. Shafey 0, Eriksen M, Ross H, et al. The Tobacco Atlas. 3rd edn. Atlanta, GA: American Cancer Society, 2009.

99. Instituto Carlos Slim de la Salud. Vive Sano. 2010. http://www.salud.carlosslim. org/nuestrosprogramas/Paginas/ViveSano.aspx (accessed 19 Aug 2010).

100. Instituto Carlos Slim de la Salud. Vive Sano-Objectivos. 2010. http://www salud.carlosslim.org/nuestrosprogramas/Paginas/vive_sano02.aspx (accessed 19 Aug 2010).

101. Centers for Disease Control and Prevention. Best practices for comprehensive tobacco control programs-2007. 2007. http://www.cdc.gov/tobacco/ tobacco control programs/stateandcommunity/best practices/pdfs/2007/ BestPractices_Complete.pdf (accessed 18 Aug 2007).

102. Instituto Car̄os Slim de la Salud. Presentación pública. 2008. http://www.salud. carlosslim.org/Paginas\%20NEP/ev 007 2008_p01.aspx (accessed 19 Aug 2008).

103. Pan American Health Organization. PAHO: tobacco use, tobacco related mortality and exposure to tobacco smoke. 2002-2005. http://www.paho.org/ tobacco/CountriesTopic.asp?Countryld=0\&Topicld=49 (accessed 12 Jan 2002-2005).
104. Hurst SA, Mauron A. A question of method: the ethics of managing conflicts of interest. EMBO Reports 2008;9:119-23.

105. Axelrod R. Conflict of Interest: a Theory of Divergent Goals with Applications to Politics. Chicago: Markham Publishing, 1970.

106. World Health Organization. Declaration of interests for WHO experts. 2000. http://www. who.int/ipcs/publications/cicad/en/Declaration of interest.pdf (accessed 13 Nov 2000).

107. Fontanarosa PB, Flanagin A, DeAngelis CD. Reporting conflicts of interest, financial aspects of research, and role of sponsors in funded studies. Journal of the American Medical Association 2005;294:110-11.

108. May L. Conflict of interest. In: Wueste DE, ed. Professional Ethics and Social Responsibility. Lanham MD: Rowman \& Littlefield, 1994.

109. Zeltner T, Kessler DA, Martiny A, et al. Tobacco Company Strategies to Undermine Tobacco Control Activities at the World Health Organization. Report of the Committee of Experts on Tobacco Industry Documents. 2000. http://www.who.int/ tobacco/media/en/who inquiry.pdf (accessed 15 May 2000).

110. Kin $\mathbf{F}$, Assunta M. Tobacco industry intereference in health policy in ASEAN countries. 2009. http://resources.seatca.org/Tobacco\%20Industry\%20Interference. pdf (accessed 20 Sep 2009).

111. World Health Organization. Tobacco Industry Interference With Tobacco Control. Geneva: WHO Press, 2009

112. World Health Assembly. WHA54.18: Transparency in tobacco control process. 2001. http://apps. who.int/gb/archive/pdf files/WHA54/ea54r18.pdf laccessed 22 Jun 2001).

113. World Health Organization. WHO report on the global tobacco epidemic, 2008 The MPOWER package. 2008. http://www.who.int/tobacco/mpower/ mpower_report_full_2008.pdf (accessed 15 Dec 2008).

114. LeGresley E. Understanding the tobacco industry: a "vector analysis" of the tobacco epidemic. Bulletin Medicus Mundi 1999. http://www.medicusmundi.ch/ $\mathrm{mms} /$ services/bulletin/bulletin199901/kap01/03legresley.html laccessed 1 Nov 2010).

115. Biancoa E, Champagnea B, Barnoya J. The tobacco epidemic in Latin America and the Caribbean: A Snapshot. Prev Control 2005:1:311-17.

116. World Health Organization. WHO inquiry [on tobacco industry influence]. 2004 http://www.who.int/tobacco/policy/who_inquiry/en/print.html (accessed 22 Jun 2004).

117. Saloojee Y, Dagli E. Tobacco industry tactics for resisting public policy on health Bull World Health Organ 2000;78:902-10.

118. Herman R. Incoming HSPH Dean Julio Frenk Receives Clinton Global Citizen Award 2008. http://www.hsph.harvard.edu/news/press-releases/2008-releases/julio-frenkreceives-clinton-global-citizen-award.html (accessed 31 Mar 2008)

119. Cáncer de Mama: Tómatelo a Pecho. International seminar breast cancer: challenges and responses. 2008. http://www.tomateloapecho.org.mx/ Archivos\%20web\%20TAP/SEMINARIO\%20HARVARD/agenda.pdf (accessed 18 Nov 2008).

120. Todkill AM. Editorial: tobacco control and the collateral damage of conflict of interest. Open Medicine 2010;4. http://www.openmedicine.ca/article/view/411/ 325. (accessed 1 Nov 2010)

121. Boucher P. Reader comments: A few remarks about IDRC. Open Medicine 2010. http://www.openmedicine.ca/comment/view/411/325/28 laccessed 1 Nov 2010).

122. African Tobacco Control Alliance. African health group welcome Gates Foundation action to shield public health policies from tobacco industry. 2010. http://www.atca-africa.org/version_anglaise/ATCA_media_release_YS1_edit.pdf (accessed 30 May 2010).

123. Bill \& Melinda Gates Foundation. Statement regarding IDRC tobacco control grant. 2010. http://www. gatesfoundation.org/press-releases/Pages/statement-onidrc-grant-100412.aspx (accessed 11 May 2010).

124. Chapman S. Health and philanthropy-the tobacco connection. Lancet. Published Online First: 25 Aug 2010. doi:10.1016/S0140-6736(10)61036-7.

125. People's Health Movement. Global Health Watch 2: An Alternative World Health Report. London: Zed Books, 2008.

126. Brundtland GH. Speech to the fifty-first world health assembly Geneva, 13 May 1998. 1998. http://www.who.int/director-general/speeches/1998/english/dgspeech \%20wha98\%20eadiv6.pdf (accessed 30 May 1998).

127. Richter J. Public-Private Partnerships and International Health Policy-Making. How can public interests be safeguarded? 2004. http://gaspp.stakes.fi/EN/publications/ books/index.htm (accessed 30 May 2004).

128. Buse K. Governing public-private infectious disease partnerships. Brown Journal of World Affairs 2004;10:225-42.

129. Buse K. Governing Partnership - A Comparative Analysis of the Organizational and Managerial Arrangements of 18 Global Public-Private Health Partnerships. Geneve: Initiative for Public-Private Partnerships for Health, 2003.

130. Richter J. Public-private partnerships and health for all - How can WHO safeguard public interests? 2004. http://gaspp.stakes.decenturl.com/nr-rdonlyres-8f169cdc9a01 (accessed 3 Feb 2004).

131. World Health Organization. Guidelines on working with the commercial sector to achieve health outcomes. Report of the Secretariat. 2000. http://apps.who.int/gb/ archive/pdf files/EB107/ee20.pdf (accessed 28 Apr 2000).

132. World Health Organization. Partnerships: report by the secretariat. EB124/23. 2009. http://www.who.int/gb/ebwha/pdf_files/EB124/B124_23-en.pdf (accessed 6 Apr 2009). 